\title{
A Publisher's View of College Library Opportunities
}

By THEODORE WALLER

$\mathrm{C}$

MOLLEGE AND UNIVERSITY LIBRARIANS

have a special role-unique responsibilities and opportunities. The college librarian can be a bridge between the rest of the profession and the academic world. He can interpret the interests and objectives of the library world to the academes and bring the sophistications and insights of the academy to his fellow librarians.

If this is to be accomplished, however, the college librarian must be almost equally of the college and of librarianship. Too often he is a librarian isolated in the university community or a scholar remote from general librarianship.

There are a number of areas in which the college librarian can make a very special and unique contribution:

1. Recruitment for librarianship.

2. Strengthening the role of the college and university in the development of lifetime reading habits.

3. The evolvement of a program to strengthen library public relations, profession-wide and with special reference to college library problems.

4. Interpretation of major intellectual, scientific, and technological developments of concern to other branches of librarianship.

5. Planning the role of the library in the "exploded" college.

We certainly need to take a new look at recruitment for librarianship. We need a considerable increment in the quantity of librarians being recruited and an improvement in the general quality level. Any discussion of recruiting needs to be in juxtaposition to an investigation of the division of labor be-
Mr. Waller is Vice-President, The Grolier Society, Inc., and the Americana Corporation. This article is adapted from a paper presented at the College and University Section of the Louisiana Library Association, Mon. roe, March 25, 1960.

tween professionals and nonprofessionals within the library. Considerable professional talent could obviously be freed if we were to relax and update somewhat the prevailing orthodoxy with respect to library functions requiring professional training. Something might be learned here from the educators who, in the socalled team teaching concept, are making use of classroom assistants, reserving the teacher for functions which require his special expertise and background.

It is apparent that college and university librarians might profitably involve themselves far more fully in recruiting for librarianship, both informally and as a part of ALA's person-to-person recruiting campaign. Other professions invest very substantial resources in recruiting: nursing, social service, teaching, to name only a few, have well financed high priority recruiting operations. If we compare the resources invested in recruiting for librarianship, the evidence would suggest that we accord a low priority to recruitment. The situation can be corrected, in part, by strengthening the recruiting resources available to ALA. More important, however, the profession as a whole, and college and university librarians in particular, might take a more explicit and urgent view of their opportunities and responsibilities in this area. Why, we may ask, do 10 per cent of the 
colleges supply 60 per cent of graduate library school students? Perhaps those college libraries that are most effective in interesting students in librarianship have been particularly successful in one variation or another of the internship idea. Certainly the exposure of a student with predilections toward librarianship to a vital, intellectually deciding college library program is recruiting at its best. The commitment of many fine college librarians to efforts of this kind, however, would not seem to discharge fully their obligations to contribute to a professionwide recruiting program.

There is something to be learned from the North Carolina experiment as reported by the North Carolina Council on Librarianship. Here all segments of the profession have banded together in a statewide demonstration of a wide variety of recruiting techniques. Whatever else the North Carolina experiment may demonstrate it would seem conclusively to establish the desirability of aggressive and dynamic cooperation at the state level among all branches of the profession.

A study has recently been designed to explore the percentage of the top 10 per cent of certain high school and college student bodies that select educational administration as a career. The concern here is that, Dr. Conant and Admiral Rickover asicle, it is going to be difficult significantly to upgrade American education unless and until an appropriate percentage of the most gifted young people in the country turn to school administration as a career.

What about librarianship? How many of the very ablest students in our institutions have decided by their sophomore or junior years that their destiny is in the library? And what can be done to increase that number?

Is the development of what we are currently calling lifetime reading habits a proper concern of the college and university librarians and of the total facuty?
A conference on "The Undergraduate and Lifetime Reading Interest" was held at the University of Michigan in 1958, sponsored by the National Book Committee and directed by Dr. Frederick Wagman, to explore the extent to which college experience leads to lifetime reading and to continuing self-education. Can we not agree that the college and university library should have a specific and urgent role in developing the kind of motivation and in sparking the interest that will lead students to read creatively and develop mentally throughout their lives, that will make the college student a book-oriented man? And may I suggest, further, that the college and university librarian can effectively address himself to this problem through two channels: on the one hand by developing his own library program with these ends in mind, and second, by becoming the center of agitation in the faculty with a view to making more and more professors conscious of this mission of the university? Why shouldn't a college or university faculty, as a committee of the whole, examine the status of books and reading in the lives of the graduates of their institutions? On every campus there are a few professors who realize that whatever information and skills they may transmit, they have truly succeeded in their mission only when the love of continual learning - the lifelong appetite for knowledge-has been instilled in their students. These professors are the librarians' natural allies. This alliance might well reorient the academic program on many a campus. In this connection we may take as our text the book published by the University of Michigan Press, Reading for Life, a report on the National Book Committee University of Michigan Conference.

Harold K. Guinzberg has written ${ }^{1}$ about the dearth of retail book outlets in college communities. This, too, is cer-

\footnotetext{
1 Reading for Life (Ann Arbor, Mich.: University of Michigan Press, 1959).
} 
tainly a subject of compelling interest to college librarians, as it is to publishers.

The subject of conventional public relations is anathema to many college librarians. In the very nature of things, National Library Week was abhorrent or, at least, an object of slightly irritated tolerance to many if not most ACRL people. Somehow, the more handsomely such promotion and public relations programs succeed, the less many college librarians like them, or so we have been led to believe. But doesn't this whole question need a new look? Don't we want much closer and more functional ties between college and university librarians and the rest of the profession, notably public librarians and school librarians? Is it not more than desirable for college librarians to exercise strengthened leadership profession-wide and particularly in such projects as National Library Week, and, apart from obligations to the rest of the profession, might not $\mathrm{Na}$ tional Library Week be an opportunity to do some fundamental interpreting of the college library role to faculty, trustees, and student body? Further, is it not possible that in many situations Library Week would provide the occasion for making the local community more conscious of the college or university library and its role in the institution? Which is not to deny that many college and university librarians devote great energy and imagination to interpreting the library to students, faculty, and townspeople. We must be careful to avoid letting this argument run aground on semantic shoals. Any well administered college or university library, of course, has an aggressive "public relations" program ranging from work with "the friends of the library" to exhibits. Here, however, we address ourselves, as in the case of recruiting, less to what is being done in individual libraries than to the opportunity for college library participation in profession-wide programs. And, as with the other matters with which this paper is concerned, these points are made with the greatest circumspection. The "view" taken here may not be wholly appropriate to the subject.

In this enumeration of challenges and opportunities, we mentioned interpreting major intellectual, scientific, and technological developments of concern to other branches of librarianship to the rest of the profession. We are in a period not only of explosion of general knowledge but of incipient revolution in several phases of education. Librarians are either going to be part of the inner circle, planning and guiding these striking developments, or they are going to be service personnel passively at the command of trends.

As an example, there is the matter of educational television. In less than a year the Council for Airborne Instructional Television is going to put a DC$6 \mathrm{~B}$ in orbit over Lafayette, Indiana, and through transmitters in that airplane broadcast twenty-four (possibly seventysix) half-hour programs a day to a fivestate area with a potential audience of five million children. These programs will be at the elementary, secondary school, and college level. The project has been made possible by a grant from the Ford Foundation and through the significant financial support of half a dozen of the greatest industrial enterprises in the country. The Council is being directed by the able John Ivey, recently vice-president of New York University. This is a demonstration. It may become a permanent part of the educational pattern in the area and lead to other comparable projects. Ten airplanes could blanket the country. It may not be long before more sophisticated devices than a DC-6 will be used for transmission.

Even if this project does not succeed per se it is certain to be effective shock therapy. It is certain to introduce new ideas, new techniques, new concepts to educators in that region and nationally. 
The television teachers are now being recruited. They will be brought together for a period of training at Purdue and then will operate from production centers adjacent to their homes. All broadcasting will be from video tape. In the five-state area thirty regional centers will be established on thirty college campuses. These centers staffed with project personnel will help schools tool-up both mechanically and educationally. They will train elementary, secondary school, and college faculties in the use of this educational television.

Where are librarians in this picture? Shouldn't they be in the very middle of the act? If library insights and skills are brought to bear early, intensively, and consistently, will this unprecedented venture in educational television not result in infinitely increased use of the library, either school library or university library? Will it not make independent study, reading, and research a far more significant part of the individual student's academic life?

But is this inevitable?

Finally, how about the role of the library in the "exploded" college? In ten years there is no doubt that double the number of college students will require more than double the present library facilities. More library resources will be needed to deal with more students and more faculty and vastly more knowledge. Existing institutions must undoubtedly expand their book budgets. There is, of course, local planning on many campuses to deal with the anticipated problems. But who is worrying about college and university library planning nationally?

The increase in enrollment will occur in institutions least equipped to provide library service-junior colleges burgeoning into universities, community colleges, state teachers colleges. The weight of the increase in the national college student body will not be in established institutions which can, after all, in some considerable degree control the size of their student bodies by adjusting entrance requirements. It will be in these new institutions or newly significant institutions. Is it too much to suggest that lack of adequate library facilities in these latent universities is a critical national problem?

Where are the college librarians to come from? Will the administrations and legislatures understand that substantial resources will be required to build collections from scratch or are we going to have sumptuous library buildings relatively barren of materials? Is the old Shaw list adequate to meet this challenge? Don't we urgently need more new thinking and profession-wide action here? Might it not be appropriate for college and university librarians to put the weight of their profession behind proposals for a national study?

Many college librarians would be surprised to know how many publishers and National Book Committee-type citizens have an acute interest in the problems of college and university libraries. The college and university library is everybody's business. It is the business of the student body, of the faculty as a whole, of the library profession as a whole, of everybody in the national community who is concerned about books and reading. College librarians have strong allies in the National Book Committee and among the citizens across the country who have been involved in National $\mathrm{Li}$ brary Week. 